\title{
THE ROLE OF THE INDIGENOUS KNOWLEDGE SYSTEM OF THE COMMUNITY Model Intergovernmental Cooperation in Education Program Guide in the province of South Sulawesi
}

\author{
Suryadi Lambali
}

\begin{abstract}
Noting the fact that the index of the quality of primary and secondary education in the province of South Sulawesi, which was ranked 21 out of 34 provinces that exist throughout Indonesia (2009), the South Sulawesi provisional government is determined to improve the quality of education index to rank 10 (2013). To support these policies then issued Regional Regulation No. 4 of 2009 concerning free education program which was further supplemented by the Governor Regulation No. 4 of 2011 on the implementation of the free education program. The program is held by a model of cooperation between the provincial government and the government district/city in South Sulawesi. Particularly in relation to the distribution of the proportion of the budget given for each level of government. It was agreed that the provincial government issued a budget of $40 \%$ and district / municipal governments $60 \%$. In the implementation until 2016 (approximately 8 years) has not shown a significant index of the quality of education, because it is still ranked 19. The objective of this study is to analyze why the model of cooperation among government used in its free education program has not been effective. To achieve these objectives, the research approach used is qualitative types of cases. The results showed that the model of intergovernmental cooperation that is used is politics society and politics of inter-organization and not used of legal and administrative approaches.
\end{abstract}

Key word: Intergovernmental cooperation, Politics Society and Inter-Organization, legal and administrative approaches

\section{INTRODUCTION}

\subsection{Background}

The potential to accelerate the successful development and welfare of people in an area, one of which is highly dependent superiority of human resources. Awareness to develop the potential of every moment is already very high wailayah not driven by international institutions to achieve the targets in the Millennium Development Gold (MDG) but also a common awareness in every region in Indonesia. Not least in the province of South Sulawesi. Through free education program that have been proposed since the early reign of Sulawesi Governor in 2008 until now. If examined closely, the real free education program is not only open up wider access to the child is unable to make schooling free of charge. Moreover, this program will gradually break the chain of poverty, restore the rights of children, as well humanize those who have been oppressed by the power of capital.

"Free Education" here is the commitment of the government in providing education without involving the community (parents) in terms of financing, particularly for school operations. Above understanding has a consequence that the free education policy heavily dependent on the accuracy of the calculation of the unit cost (unit cost) in the school. The unit cost provides an overview of how the actual average cost (the real average cost) required by the school to serve the students. The cost of the unit should then be compared with BOS (school operational assistance) the difference is covered by local governments 
through regulation of the budget that has been set in the budgets of provinces, districts and cities. This is what we mean by the term sharing of funds between central and local governments.

The success of the development program is not always successful when the government as responsible for the success of development in the region are not able to design policies once mengimplementasikannnya effectively. Free education policy in question is in order to overcome the low quality of education in South Sulawesi as part of indicators of human development index (HDI). Before the free education policy implemented, the province of South Sulawesi its HDI is still at number 21 nationally, including education. Because the South Sulawesi provincial government in cooperation with the district / city government seeks to improve the quality of education through a Memorandum of Understanding (MOU) which was followed by the Regional Regulation (Perda) No. 4 Year 2009, contains on the Implementation of Free Education in South Sulawesi province. Bylaw No. 4 In 2009 this was followed up by the Governor Regulation (gubernatorial) No. 9 of 2010 which contains the Guidelines for Free Education South Sulawesi province. The budget for education free trial in 11 regions ranged from Rp 644 billion sourced from school operational funds (BOS) to Rp 405 billion, Rp 125 billion provincial budget, and the rest of the state budget heading. Free education program in South Sulawesi are expected to have implications for the reduction in the illiteracy rate among school age.

When referring to the Regulation No. 4 of 2009, the goal rather than free education is; 1) improving equitable learning opportunities for all children of school age; 2) improve the quality of graduates; 3 ) improve the relevance of competency-based education to keep pace with global developments; 4) increase of efficiency and effectiveness of the implementation of free education to meet the quality and productivity of human resources excellence. In the law chapters 2 and 3 are also presented scope of free education. The scope of these is that free education; 1) is intended for the people of South Sulawesi who send their children in primary and secondary schools in South Sulawesi; and 2) for students who come from outside South Sulawesi education but charged according to applicable regulations. While the principle used in the implementation of free education that is based on the equity, quality assurance, participation, transparency, accountability, education, and competency.

In 2001 alone, the education budget has significantly increased eight-fold from 42.3 billion (2001) to 200 billion in 2009. Free Schools Program Policies for elementary and junior high school launched by the government in 2009 has increased the BOS allocation per student per year in 2012 reached Rp. 580,000, - per primary school student and Rp. 710,000, - per junior high school students. Unfortunately, the surge in the education budget has not been able to answer still finding people who are not able to enjoy education, especially those from poor households (Kopel and Tifa Foundation, 2012).

In findings Kopel and the Tifa Foundation, revealed four (4) major problems that are often found in the implementation of the Education Fund. First, regulation is needed to strengthen the protection of citizens' rights at a time of accountability implementation. Second, budget accountability is still low, especially in the absence of strict sanctions and legal action. Third, overlapping authority, and the fourth, the low supervision of Parliament and the media. In particular, the issue of education is seen still minimal media attention. The budget allocation is also an indication of less efficient, causing free education not being reached. In many areas, for example, the increase in the education budget more absorbed by indirect spending (especially the salary component), which direct spending posture education (program spending) is relatively fixed or even declining. Therefore, the exact opposite of a surge in the budget, education urgency Indonesia in fact it is still just dwell on the problem of improving the quality and equity of access than even its governance. Standard with policy tools that have been available have not been effective, improved funding scheme areas that do not support the policy of free education, the data collection system (especially the school's data against the data students from poor households) are still not accurate, yet effective system of supervision tiered systemic, integrated so that implementation program ineffective. 
Conceptually issues that arise in the process of cooperation between local governments in the free education policy led by the government of South Sulawesi Provoinsi not be separated from the ineffectiveness of cooperation between the local governments. If the South Sulawesi provincial government together with local government district / city using a model of intergovernmental cooperation (intergovernmental cooperation), it can be assumed that the issues that arise as previously described will not appear and even insurmountable. Because according Agranof (1986); and Conlan and Posner (2008), the policy of cooperation relations between the local government can be a solution to various problems disparities between regions, particularly in the empowerment of community participation in improving the efficiency and effectiveness of resource utilization in order to create development that is harmonious and balanced, appropriate position, role and its functions with due regard to the principles of democracy, diversity potential of each within an integrated management (Arganoff, 1986; Laffin, 2007; Tasmaya, 2007). To be a model of cooperation among the regional administration managed, policy is needed to coordinate activities between one or more local governments (Post, 2002). Cooperation among governments at the local level will also be the arrangement of two or more of government to achieve common goals, providing services or resolve problems together (Patterson, 2008; Domai 2009; Warsono 2009; Coon, 2011). Cooperation between government tiers below the top level with a conceptually named as a form of intergovernmental relationship (IGR). On the basis of these considerations that the study was conducted. The goal was to understand and analyze the various issues that arise in the free education program between the provincial government and the government of South Sulawesi regency / municipality that has finally found a model of cooperation between the governments.

\subsection{Formulation of the problem}

1. How is the importance of cooperation among local governments in gratisi education program in South Sulawesi?

2. What are the factors that influence the intergovernmental cooperation with the government of South Sulawesi Province District / City in the free education program?

3. How is the relationship model of cooperation among local governments in the free education program in South Sulawesi province.

1.3. Research purposes

Finding a model of cooperation relations between the regional government in the free education program in South Sulawesi province.

\section{LITERATURE REVIEW}

In Indonesia, the basic organizing the cooperation relations between the local government (intergovernmental cooperation) is a development concept of the relationship between the government (intergovernmental relations) and the management of inter- governmental (intergovernmental management) that developed in the study of decentralization (local autonomy) that focused on each activity or interaction between units -unit of governance, allocation decisions are based on what, who is involved and the consequences of those actions (Smith, 1985; Anderson's, 1960; Edner, 1976, Arganof, 1986; Conlan and Posner, 2008). The integration of the concept into three basic reference in drafting model of the relationship of cooperation between regions that have a high level of effectiveness in achieving the objectives of cooperation.

Conceptually relations of cooperation between the regions to explain how regional administration can be more effective and efficient in conducting collective action. Effective in eliminating managerial fragmentation in governance, so as to create equitable development. Accession process through cooperation undertaken since the beginning of the management process and act together (Anderson, 1960; Edner, 1976; Agranof, 1986). Thus the intergovernmental management is an integrated management controlled together in the face of complexity (Agranof, 2003). Free education in order to 
be sustainable it needs the support of inter-regional cooperation relations policy. Cooperation between governments is intended to reduce regional disparities, reduce conflict, improve service, empowerment of community participation and improve the efficiency and effectiveness of resource use, to realize the construction of the harmonious and balanced, appropriate position, roles and functions with regard to democratic principles, the diversity of the potential of each within an integrated management (Tasmaya, 2007).

Theoretical reference used in building models of cooperation relations between the local governments in the free education policy in the province of South Sulawesi is a model of cooperation relations between the government, according to Henry (2004). Model partnerships between local governments in the free education policy in the province of South Sulawesi, namely: 1) joint service agreement; 2) intergovernmental transfer service, and 3) pattern of interlocalism (Henry, 2004).

Research on the relationship of cooperation between local governments in the free education policy in the province of South Sulawesi is designed in order to find a model of cooperation between governmental relations in the field of free education in the province of South Sulawesi. Model form of cooperation relations between the regional government allows the sets of students no longer have problems in getting a quality education so that the basic needs of those preparing for the future, especially in the aspect of education can they feel. Learners and their families who are less able no longer fend for themselves in taste education, but getting support from local authorities, in any form of policy, strategy and infrastructure as an integral part of the function of the service provider to the public of quality and equitable.

Based on the concepts and theories of exposure the cooperation relations between the regional administration with a focus on free education in the province of South Sulawesi, the authors describe the state of the art research, below.

Model partnerships between local governments in the free education program in South Sulawesi

1. Identify why the cooperation between local governments is essential in a free educational program

2. Identify the factors that affect the cooperation between the government free education program

3. Theapproachusedinintergovernmental cooperation in the free education program

\subsection{Roadmap Research}

Studies on the relationship of cooperation between the government known several stages, ie the stage of determining strategy or decision-making or policy-making, public service delivery stage, the stage of 354 
policy implementation, and evaluation phase (Hill, 2002). In this regard, other researchers have done some of those stages, namely the network in defining a strategy and stages of implementation of public service. At the phasing of other researchers have conducted research at the stage of defining a strategy, stage of public service delivery, today will conduct research on policy implementation stage. For more details can be seen in the image below.

Figur 1 Mapping of the research

\begin{tabular}{|l|l|l|}
\hline \multicolumn{2}{|l|}{ Stage Research Intergovernmental Cooperation } \\
\hline $\begin{array}{l}\text { Decentralization Policy } \\
\text { (autonomy) }\end{array}$ & $\begin{array}{l}\text { Implementation of Cooperation } \\
\text { Between Government Level }\end{array}$ & Strategy / Model Cooperation \\
\hline
\end{tabular}

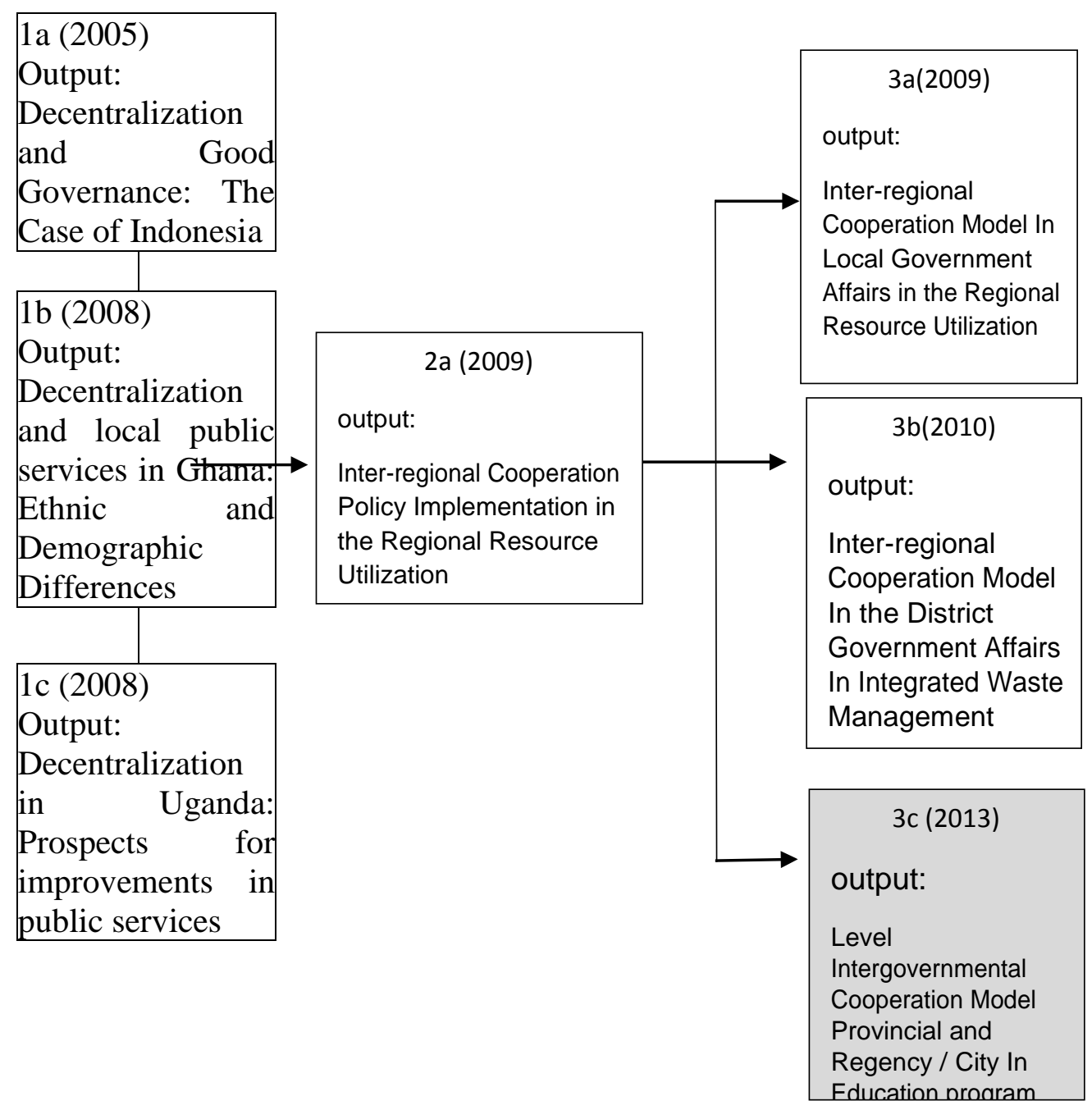

Based on the picture-1 above shows this study complements a couple of models of cooperation among governments, but rather focus on cooperation between the provincial government and district / city in the lower levels of government, especially in the free education program. Previous research contribute to the research to be done, especially in finding the reasons, factors and approaches used in the intergovernmental cooperation in South Sulawesi

\section{RESEARCH METHODS}




\subsection{Location Research}

The research location is the province of South Sulawesi which is where the implementation of free education. The location of the sample study is an area which is considered to represent the province of South Sulawesi is Makassar City Pare-Pare (representing urban areas), Gowa (representing the district closer from the provincial capital), and the district of Luwu Utara (representing districts far from the provincial capital).

\subsection{Design and Strategy Research}

This study was a qualitative case study research strategy. Use of the design of such research is to unveil a model of cooperation between governments based on the context. In the case study, there are two types of research, which is descriptive, and eksplanatif (Yin, 2000).

\subsection{Informants}

Determination of informants in the study were determined purposively, that they are deemed to have information or be involved either directly or indirectly to the free education program in South Sulawesi province. Such determination was based on the assessment of the experts (or the researchers themselves) for a particular purpose or a particular situation (Neuman, 1997).

The informants in this study are: a) The Regent / officials and employees of the Department of Education; b) a team of nine free education program South Sulawesi province; c) members of the Commission in Parliament that gave birth to the education sector; d) Provincial and District Education Council.

\subsection{Data Collection Techniques}

In this study, data collection techniques used were observation, interview, and documents. Observations were made primarily related to the object, such as a school, and a variety of facilities and infrastructure support free education. Depth interviews were conducted at the informants mentioned above, while the technical documentation is to collect documents such as regulations, journals, and research results related to this research.

\subsection{Mechanical Processing and Data Analysis}

In qualitative research data analysis and processing is an activity inseparable. It can be seen on the stages of the qualitative data analysis proposed by Miles and Huberman (1992), namely: data reduction, data presentation, and conclusion / verification. This study uses a case study analysis strategy, in which the analysis carried out varies from one stage to another stage.

\section{RESULTS AND RESEARCH FINDINGS \\ 4.1. An Overview of Research Object}

Free education policy in the province of South Sulawesi is a policy issued by the local government, especially in the era of the leadership of the provincial governor of South Sulawesi Dr. Syahrul Yasin Limpo, SH., MH., As part of his political appointments when participating in the election of the Governor of South Sulawesi province in 2009. After Syahrul Yasin Limpo was elected governor of political appointments he subsequently poured into Regional Regulation (Perda) No. 4 2009. in the law does set some basic principles that show how the collective responsibility that must be carried by all levels of government in the province of South Sulawesi (province-district / city). The principle is:

a. Free education is a policy with a financing scheme elementary and secondary education are addressed jointly by the Provincial Government and the 
Government of Regency / City in order freeing the cost of education of students in the region of South Sulawesi provision.

b. Regarding the allocation of funding education governance based on each school's profile educational unit. To the provincial government verification of each school's profile.

Through Regulation No. 4 of 2009, the government of South Sulawesi province following up with a Memorandum of Understanding (MOU) with the government of the level of district/city. A strong desire to realize South Sulawesi province excel in the education sector can not be separated from the development vision of South Sulawesi Province, 2008-2013 namely: South Sulawesi province into ten best in the construction of basic rights. The Vision subsequent elaboration into the development vision of the education sector, namely: South Sulawesi ten best fulfillment of basic rights in education. Ten indicators are measured through performance indicators and service of basic rights of education sector is measured through the provision of facilities to the community based on the competencies of the Provincial Government in the form of service development and regulation of the education sector.

South Sulawesi Provincial education vision subsequently poured into the educational mission, namely:

1. Improving management of educational services;

2. Improving access and equity in education;

3. Improving the quality and relevance of education;

4. Improving literacy and reading culture in society; and

5. Develop and utilize ICT.

While the goals and objectives set forth by the intention to realize its vision and mission. The objectives and targets are also meant to be the direction for every attitude and behavior of the free education providers. The education objectives with respect to:

1) affordability of educational services; 2 ) opportunity to obtain a quality education; 3 ) improvement of knowledge and knowledge development; and 4) institutional development. The goal of free education are: 1) an increase in the average length of the school (RLS) of 8.3 years; 2) an increase in the literacy rate (AMH) reached $95 \% ; 3$ ) a decrease in dropout rate / school center (DO) for students of Elementary School (SD) of 0.7\%, Junior High School (SMP) to 1:00\%, High School (SMA) and Vocational High School (SMK) to $1: 00 \% ; 4)$ increasing the transition rate (AM) for primary to secondary school graduates reached $98 \%$, SMP to SMA / SMK reached 95\%; and 5) the addition of S3 qualification for educators, staff, employees and education observers to 500 people.

Free education scheme and industrial cooperation between the provincial governments and district / city governments do with the financing patterns in which $60 \%$ of the costs borne by the district / city, while $40 \%$ is paid by the provincial government.

In order that the implementation of free education done well, then Bylaw No. 4 of 2009 selanjutya poured into South Sulawesi Governor Regulation No. 4 of 2011 on the Implementation of Free Education in South Sulawesi province. The implementation scheme can be viewed via the following picture:

The organizational structure of the implementation of free education in the province of South Sulawesi, namely:

Control Team at the Provincial Level

a. protector:

- The Governor of South Sulawesi 
- Deputy Governor of South Sulawesi Province

- Chairman of the Parliament of South Sulawesi Province

b. Steering:

- South Sulawesi Provincial Secretary

- Chairman of Commission IV DPRD South Sulawesi Province

- Head of the South Sulawesi Provincial Bappeda

- Chairman of the Board of Education of South Sulawesi Province

c. Executing:

- Chairman: Head of the South Sulawesi Provincial Education Department

- Vice Chairman: MORA Kakanwil Regency / City

- Vice Chairman: Deputy Head of South Sulawesi Provincial Education

- Secretary: Head of Education Department of Primary Education Prov. Sulsel

- Deputy Secretary: Head of TU MONE Prov. South Sulawesi

- Deputy Secretary: Head Mapenda Affairs offices Prov. Sulsel

Tim controllers Regency / City

- Coordinator Regency / City. Member:

d. protector:

- Regent / Mayor

- Deputy Regent / Deputy Mayor

- Chairman of Regency / City

e. Steering:

- District Secretary / City

- Chairman of the Parliament Committee for Education

- Head of Regional Development Planning Agency / City

- Chairman of the Board of Education District / City

f. Executing:

Chairman: Head of District Education Office / City Vice Chairman: MORA Kakanwil Regency / City Vice Chairman: Deputy Head of Education District / City

Secretary: Head of Primary Education District Education Office / City Vice discharge: Head of Education of TU / City

Vice discharge: Head Mapenda Affairs offices District / City Members: Koordinatir Subdistrict

Tim Sekteraris Free Education Program in each district / city of South Sulawesi.

\subsection{Research result}

The ultimate goal to be achieved and the end product of research suggests in relationship model of cooperation among local governments in the free education program in South Sulawesi province. To achieve the ultimate goal of this research, this study was planned in two phases where the first phase reasons why cooperation among local governments is essential to do or how its significance at both levels of government (Provinsi- District / City) wishes to engage in inter-governmental especially in the free education program in South Sulawesi. In addition to these objectives also in this study explored what are the factors that influence the cooperation between the provincial government of South Sulawesi regency / municipal government.

4.2.1. The significance of cooperation among local governments in the free education program in South Sulawesi province.

In expressing the importance of cooperation among local governments in the free education program in South Sulawesi Province, referring to some of the main questions is the reference to illustrate the importance of this cooperation is done. The questions are: how to form partnerships between the 
provincial government and district in the field of free education; What is the legal basis of cooperation between the provincial and district / city; What's the reason the cooperation between the provincial and district / city; What is due to administrative reasons, what for political reasons, what for economic reasons? The first analysis disclosed in the context of the importance of cooperation among local governments in free education in the province of South Sulawesi is how to shape relations of cooperation between the provincial and district / city. Summing up what form cooperative relationships can be known through a series of information obtained from a variety of key informants in each district / city object being studied.

According to information from a variety of key informants and combined with existing documents can be seen that the free education policy is a policy scheme designed specifically which aims to improve the quality of education outcomes in the province of South Sulawesi, especially at the level of primary and secondary education. As it is known that during this rank quality primary and secondary education South Sulawesi province at the beginning of this policy is rolled out through political appointments at that time the candidate for governor Syahrul Yasin Limpo (1998) still be around 20-22 ratings from all provinces in Indonesia. This was confirmed by one informant Education Commission Chairman 2 ParePare Parliament which states that:

"... So far as I know, since the beginning of the story that time governor candidate who now has served the governor campaigned for free education programs and free health care. Then finally after being chosen forwarded to the areas then become the program and then became a candidate campaign regents I mayors of each area included in the town of Pare-Pare. That was the beginning of the program appears "(IJ: 2015)

To realize that such schemes can be implemented, chairman was elected governor of the political promise be realized in the form of Regional Regulation No. 4 of 2009. Efforts to realize the policy it seems difficult at the time when the entire financing should come from the local budget (APBD) South Sulawesi province alone. Because the South Sulawesi provincial government invited the district / city governments to join together to make that free education. Through a Memorandum of Understanding (MOU) between the government of the province of South Sulawesi with the Regent / Mayor as much as 23 City District, then the policy could be operationalized. Form of financing was agreed to be tackled jointly between the provincial government to district / city governments. In the MOU, it was agreed that the allocation of funds to each provincial government levels, namely by $40 \%$ and the government district / city level by $60 \%$.

Thus, the legal basis of cooperation between the provincial government and the district heads / mayors always refer to Regulation No. 4 of 2009. This was confirmed by one of the key informants namely the Head of Division (Head) Basic Education Department of Education Pare-Pare which states that:

".... .. We no legal basis for this cooperation free education, legal basis of the MOU between the Governor and the Mayor. Governor Regulation regulate the procedures for the use of funds for free education. Besides it is also bound by Provincial Laws On Pendidian Penyelenggaraa Internet (AI, 2015).

The MOU between the government of each province by Regency / City Government conducted independently by the characteristics of the region. For example MOU on location object being studied is between provincial governments and the City of Pare-Pare stated in the MOU No: 276/ VI/ provincial / 2013 and No. 180.4 / IIa / HKM / 2013. As for the cooperation between the provincial government of South Sulawesi with North Luwu regency government stipulated in the MOU Number: 316 / X / provincial / 2013 and No. 410 / 137.1 / Disdik.

Free education program initiated by Governor chairman is basically not a new program in South Sulawesi. Gratisi education programs have already previously among North Luwu and Sinjai. According to the Chairman of the Commission for Education 1 North Luwu Regency stated that:

"... Special ..kalau North Luwu, free education was first announced by the government of North Luwu regency in 2004. So at the time, Lutfie in the second period of the campaign, one vision will provide free 
education up to the level of secondary school (SMP), then scoop intercepted because suddenly there is a program of the provincial government is also in the form of fund sharing 40\%: 60\% (AAM, 2015)

AAM statement is further strengthened by the statement of the Chairman of the Board of Education of North Luwu which states that:

"... ...so Since 2005 I served as Chairman of the Board of Education, a free education program in North Luwu Regency is already there, sir Lutfie have saved it. Instead, pack Lutfie've gathered all the principal to explain this free education program '(MA, 2015)

This free educational program is an integrated program that includes policies financing, structuring, development, monitoring, and control. Free education in this case was intended to free the students from all kinds of school fees either directly or indirectly. The design in the form of subsidizing the cost of education in terms of school operations to offset the cost to be incurred by the school, and scholarships for students who beprestasi in order to reduce the cost of school learners.

The reason for convening the policy of free education can be parsed from the standpoint of the provincial government as described in the beginning that because look at the reality of the quality of education in South Sulawesi region remained at a level between 20-22 throughout Indonesia so that no specific policies to cope with the condition. When referring to the angle of view why the government district / city support the government's policy at the provincial level is quite varied misalya from the standpoint of the government of Pare-Pare in which constituted apart due consideration to lower the school dropout rate in the region, as well as social and political reasons as stated by the Chairman of the Commission of 2 Education Council Pare-Pare:

"... .. In fact the beginning of this cooperation that we see are due to social reasons. This means that we are planning to do a free education system but not unconnected from the political element in which the program is being "sold" during the campaign in the region (EN, 2015).

The same thing was stated by Chairman of Commission I of the Education Council North Luwu which states that: "The free education program is a populist program, where each Election directly in each district / city, would be said to succeed, so the nuances of political highly viscous (AAM, 2015) , Vice Regent of Luwu Utara stated that:

"... .. So, I have no problem with the partnership as the education sector is one of the basic needs of people who are basic services that must be met by the government, so this is a shared obligation that no provincial program, his spirit was so that no student is not in school for reasons no fees or dropped out of school because of the high cost of education, so the local government supports it (IPI, 2015).

In this free education policy required all school children completing primary and secondary education in the context of the formation of character and noble character in line with the norms of decency on the basis of God Almighty. If these obligations are ignored by the parents of students, the government is obliged to write to his parents. With this policy, the objectives of the free education as described in the general description of the object of study, namely: 1) improving equitable learning opportunities for all children of school age; 2) improve the quality of and graduates; 3) improve the relevance of competencybased education to keep pace with global developments; 4) improve the efficiency and effectiveness penyelenggaraam free education to meet the quality and productivity of human resources excellence.

Referring to Regulation No. 4 of 2009 Implementation neighbor has a number of free educational programs:

1. The program is free education for students whose schools obtain full financing aid organization of education;

2. The cost of a subsidy program for poor students whose school assistance is not full or partial financing of education provision; and

3. Program scholarships for outstanding students who come from poor families. The goal of this free education that formal education in primary and secondary education which comprises primary schools both public and private. Government Elementary School (MI), both public 
mapun private, elementary school was outstanding, Junior High School (SMP) includes SMP both public and private, MTs (MTs) both public and private, Junior High School Outstanding (SMPLB), Secondary Schools (SMA) includes both public and private, vocational schools (SMK) includes both public and private, high school Superb (SMALB) and Madrasah Aliah (MA) both public and private. The decree also explained that the Private Schools and Pesantren can accept or reject the implementation of free education. For schools that refuse it are required to guarantee the quality of teaching and learning process. Regarding further quality standards set by Governor Regulation. Private schools and boarding schools are not able to meet the quality requirements outcomes, then it must be willing to be combined with a nearby private schools within a certain time. As for private schools and boarding schools who receive free education policy but still has other components that must be financed by a subsidy, it can receive from the learners with the approval of parents through the School Committee / Parents' Association. Regarding the amount of levy for every learner must get approval from the local government based on the implementation of free education Supervisory Commission.

Allocation of budget for each learner based on the number of students, study groups, educators and other education personnel. How allocation were made by the following procedure: 1) each targeted school providing education free school profile data submitted at the start of the school year according to the format in triplicate for Controlling Team Free Education District / City. Provincial Control Team, and School Records concerned; 2) Control Team Free Education District Level Data City recapitulate schools based on the profile are sent each target school pendidian organizing free, then dikrim to Provincial Control Team; 3) Control Team Free Education recapitulate the provincial level data from Control Team Free Education district / city level based on the profile created by each school, to the implementation of free education to further propose budget allocation to the Governor.

In order that the implementation of free education can take place as a mandate that has been set forth in the law No. 4 of 2009 and the Regulation of the Governor of South Sulawesi Province No. 4 of 2011 on the Implementation of Free Education in South Sulawesi province, the government formed a Commission for Supervision of Education Implementation Guide or abbreviated Komwas Ledigra. The Supervisory Commission is an institution that was deliberately set by the provincial government specifically tasked with overseeing and controlling the implementation of the free pendidian in South Sulawesi province. The supervisory commission is independent in performing its role so that the role can help the provincial government to streamline the use and utilization of subsidy funds and improving the quality of graduate education provision free (Perda No. 4 of 2009). In the effective functioning of this Monitoring Team, the Supervisory Team for free education provision can be set in each district / city with the Decree of Regent

/ Mayor (the Governor Regulation No. 6 of 2011).

In Regulation No. 4 of 2009 mentioned, in addition to molded Control Team as described in the general description of the object, also formed Free Education Implementation Supervisory Team where the goal for the management of the free education can be effective. The effectiveness of implementation is deemed to be more effective if for each beneficiary free education was also given the threat of sanctions if violations. Therefore, the Regulation No. 4 of 2009 also stated that violations of the implementation of free education subsidies threatened with imprisonment of six months or a maximum fine of Rp. 50.000.000, - Abuse of subsidies free education provision penalized under the provisions of the legislation in force. Sanctions as specified in the regulation in the form of criminal sanctions (criminal act of violation) and / or administrative sanctions. The sanctions provided in the form; 1) employment sanctions as stipulated in the regulations on employment; 2) claims for compensation as stipulated in the regulations in the field of financial management Countries / regions; and 3) delay and / or termination of the provision of education funds bentuan free (Bylaw No. 4 of 2009). The conclusion from the above description when referring to the facts related to the relations of cooperation between the provincial and district / city, especially in terms of financing of the whole policy of free education at all 
levels of primary and secondary education that funds are shared (cost sharing), where basic cooperation rests on grounds still low quality of outcomes of learners before this cooperation program implemented. On the basis of the government at the provincial level teaching and district / city in South Sulawesi to jointly overcome the problems of the education quality. Through such cooperation Memorandum of Understanding outlined and implemented consistently.

As for the legal basis of cooperation between the government of the province of South Sulawesi is the Regional Regulation (Perda) No. 4 About About Education Implementation Guide In the province of South Sulawesi. In order for the implementation of Regulation No. 4 of 2009 to be effective especially on the technical side of operations, the Governor of South Sulawesi Governor Regulation ie driving out South Sulawesi Governor Regulation No. 6 Year 2011 on the Implementation of South Sulawesi Provincial Regulation No. 4 of 2009 on the Implementation of Free Education in South Sulawesi province.

While the reason for the implementation of free education policy in the province of South Sulawesi through cooperation between levels of government district / city based on the desire to improve the quality of education in the region of South Sulawesi. With the policy of free education penyelanggaraan expected no more children of school age who are not educated. Another reason is because of political considerations, especially for the appeal of local leaders both at the level of the provincial government and district / city, especially at times when the Regional Head Election (Election).

\subsubsection{Faktor the factors that affect the intergovernmental cooperation with the government of South Sulawesi Province District / City in the free education program}

The purpose of the analysis of the factors that influence the cooperation between the Provincial Government and the Government of Regency / City in the free education program is to elaborate on what caused the implementation of free education policy has yet to show results on target. To this end it is through key informants supported by a wide range of relevant documents, the purpose to analyze the causes can be achieved. Various information to be obtained through key informants to answer research questions through a series of questions as the following: factors that influence the effectiveness of the cooperation between the provincial government and the government kabuoaten / city; how to factor the financial capability; What kepemiminan factors and regional political interests ?; What cultural factors and the structure of local government bureaucracy ?; As set forth in the law No. 4 of 2009 that the budget allocation in free educational activities aimed at; a) improving equitable learning opportunities for all children of school age; b) improve the quality of and graduates; c) increasing the relevance of competency-based education to keep pace with global developments; d) improve the efficiency and effectiveness of the implementation of free education to meet the quality and poduktivitas superior human resources.

The facts show that what the objectives of the implementation of free education seems is still experiencing various kinds of constraints. This led to the still still beradanya level of quality of education, South Sulawesi Province, according to the version of the Human Development Index (HDI), especially in education is still in the stage 20 (2014). Browse for the cause so that the tip of the quality of education in South Sulawesi which still remain on the same level when the program was initiated in 2009. Based on information obtained from a variety of key informants can be put forward several factors considered influential by related parties directly from the program of cooperation between levels of government in the field of free education can be described as follows:

\section{Ability Factor Financial and Other Resources}

The implementation of free education policy in its implementation requires a substantial budget amidst a quality of education that is still not optimal. Various budget is absorbed not only directly related to the 
cost of teaching and learning, but also associated with the post-budget items deemed capable of supporting the teaching and learning process. As set forth in the law No. 4 of 2009 that the budget allocation in free educational activities aimed at two main targets, namely; a) free education program for students whose schools obtain full financing aid organization of education; and b) the cost of the subsidy program for poor students whose school assistance is not full or partial financing of education provision; c) a scholarship program for outstanding students who come from poor families. Although the implementation of free education based on principles of equity, quality assurance, participation, transparency, accountability, education, and competence, but the implementation is still a lot of obstacles.

One of the factors that influence the effectiveness of the cooperation between provincial governments and district / city governments are financial factors, mainly related to the contribution of each party to cooperate. As known fund sharing agreed in the MOU that has been made that the provincial government for $40 \%$, while the district / city by $60 \%$. In practice it turns every region has problems respectively, primarily related to various types of financing at the school level that everything is not able to be addressed by the local government / municipal.

According to key informants the Chairman of Commission II DPRD Education Pare-Pare:

"... ... saya Assume less effective if the provinces continue to charge more to the area. I take an example, this is now a new vision of local government in Pare-Pare is there should be no charges at all, be it the School Committee from elementary through high school. Hearing of what we do with partners the Department of Education and Schools all complain. For example, for expenses for security, cleaning service should not take on the BOS and BOP and also should not be picked from the School Committee, the case also related to educational facilities (EN, 2015).

Including complaints from the Chairman of the Education Commission of North Luwu also stated that similar things: to use education funds free of Pemrov already making use of the Guidelines and Technical Guidelines $40 \%$, but sometimes do not fit the needs of the district government (AAM, 2015).

More explicitly stated by Vice Regent of Luwu Utara that:

".... Actually, the allocation of funds from the BOS funds were allocated for free education is not effective anymore. My suggestion why not other sectors and education for students who touched which is triggered by the fund but the teacher force less untouched in terms of the vital role of the teacher (IPI, 2015).

It is inevitable that factors other than financial capability is also associated with a still uneven quality of human resources (educators) in each district / city. Although in one of the free education program there are scholarships for personnel involved but because of limited financial ability ultimately have an impact on the level of competence of equitable distribution of education and education to be able to manage the quality of teaching and learning process. Source of funding or financing, infrastructure, responsibility and commitment to make the program successful field workers free, and attitudes of field staff open to feedback and criticism from various parties in revamping its free education program is also important to be addressed.

Another thing that has been linked to the financial problems that the technical manual (Technical Guidelines) issued by the government of South Sulawesi Province was felt by the implementers of district level feel they have no creative space to anticipate the different conditions in the field. So it also affects the process of managing the fund free education in the area. In addition, some districts do not agree with the provisions of sharing of funds between the provincial and district / city, because they felt somewhat burdensome area. this was confirmed by one of the key informants Midwives Head of Basic Education In Pare-Pare City Department of Education:

".... I also have to say, free education when they want to be involved because we prepared every region is different characteristics, Pare-pare problem is not necessarily the same as the Toraja. It used to be very strict rules, and I said we could not make the rules that govern the governors specifically, critical spirit free education there, as to what the problem areas associated with education services, it actually 
must be addressed. Due to regional problems related to free education is different, then they create uniform guidelines that how? Maybe we need pants but Toraja need clothes, and guidelines states have to buy pants all, so we had to buy pants, but it was not in accordance with the principle of benefits ... "(AI, 2015)

The same thing also expressed by other key informants namely Education Commission Chairman 2 ParePare City Council stating that:

".... So now, cooperation with regional provinces 40:60. So $40 \%$ of the province and $60 \%$ of the district / city. That then finally made the complaints have sprung up in the area. The government should instead look at because this is the beginning of the program, the provincial government's supply budget, although not one hundred percent, sharingnya it should be over there (Government of South Sulawesi province) not vice versa as it is today. If it could be 80:20 or 70:30. Do almost 50:50, this name is halved again not equally. So finally a lot of problems that arise in the area with the pattern of this subdivision, including us the truth when discussing the program many issues, including us as well when doing the budget discussion this Parliament is also an issue of having to adjust the program budget, because the portion of the budget in the area are not equal with the province, while provincial certainly can not divide a large portion of the budget because it also inevitably constrained by the limitations of provincial budget ..." $(E N, 2015)$.

Besides, there is the desire of the parties in the region to funding from the provincial government is delegated entirely to the district government so it is more convenient to use in accordance with the conditions of each area. It was confirmed by the Chairman of the Commission District 1 Education Council. North Luwu, that:

"... If you want a good all funds $40 \%$ of the provincial government handed over by the district government with full financial rules submitted by the district. Last year the fund is $40 \%$, about $70 \%$ of it only for training. It is governed from the provincial government, it needs training, but in North Luwu also necessary infrastructure to support such learning labs and internet infrastructure is still lacking. During the third period of the district all educational infrastructure almost all completed a special investigation diruang classroom learning, but to libraries and laboratories is still minimal, and therefore we are more important: the infrastructure of the training and if juklat guidelines from the provincial government is not followed then there will be given a $40 \%$ the ... "(AAM, 2015)

Besides the issue of financial management, are also associated proportion of the allocation of funds for each type of funding that is deemed disproportionate by local authorities. According to them should also be given a balanced proportion to the needs of the students. This was stated by Secretary of Pare-Pare that:

".... I used to protest, free education too much to the welfare of teachers, but not what he meant. Welfare later teacher behind because there is already certified. But how the money can help the community. example buy uniforms for needy students, and then the teacher to improve the quality, such as training ... "(AMM, 2015)

The fact as has been described above indicate that the problems associated with financial factors it still needs mendapatan improvement, especially in terms of the proportion of funds sharing between provincial governments and the district between $40 \%$ provincial and $60 \%$ of districts / cities where the district / city governments perceived still very heavy because there are still many sectors in areas that still require priority for funding. As well as between species / unit financing is also important in the redesign, and that is not less important aspect of management that is not too stiff so it is seen by the area that Juknis designed by the provincial government is not too in favor of the reality on the ground which are diverse in the regional level.

\section{Factor Elite Leadership and Political Interests}

In addition to financial factors, other factors are factors of leadership and political interests of the region. Seriousness of the government both at the provincial and district / city be the deciding factor effective 
implementation of free education policy. Many local governments feel that this policy is a policy imposed by the provincial government. As a result, the district / city should attempt to run this program. Local government district / city must continue to remain there despite heavy budgetary allocations. They should carry out because if not, then the government will be faced by the public. On the other hand at the time of a change of leadership at the district / city, free education program became mandatory sales offered during the campaign, although the candidates have not known exactly how both policy management and operational techniques. A condition that occurs gets a confirmation of one key informant stated that:

"..... In fact initially the program is the provincial government, then lowered into the area. I assume this was not optimal because a lot of the problems posed. From the beginning when this program into a sales campaign in the area and then into the program, the vision and mission of the elected government of the province. Finally, as imposed on the area to be on the run, so the area is also allocating the budget because we are also dealing with the public if he refused. Then after that also all local governments are now selling campaign so that the campaign material used has become like this (IJ, 2015).

In addition to these factors are also associated with a leadership commitment of leaders at the district / city different. Differences between regions commitment because some local party felt that the free education program is actually the program initiated by the provincial government, it tought to be a greater proportion of funding than those at the local level. This makes a real commitment from the leadership at the district / city different.

\section{Organizational Structure and Management}

Another factor influencing the effectiveness of the implementation of the policy of free education in primary and secondary education in the province of South Sulawesi is the bureaucratic structure of local government. In the context of cooperation between government, the organizational structure

/ bureaucracy are factors that often affect the effectiveness of cooperation as it relates in addition to a coordination mechanism among organizational units, is also associated with the emergence of conflicts as a result of the intersection of relations unit public organization (unit area devices eat it), both vertically (intergovernmental) and horizontally between government and the public (state-society). Especially in the context of modern government no longer puts the government as a single actor in the making of public policy and public service delivery.

In substance, existing governance structures in order to control all the activities and the authority that accompanies each actor as well as a steering and guidelines for the management and staff who occupy every structure and existing positions in the bureaucracy. The bureaucratic structure will be effective when coupled with proper management, especially joint management controlled well together. Complexity is happening in the relationship of cooperation between the regional administration generally in line with the complexity that occurs in each program, which also has a different jurisdiction boundaries. Agranoff (2003) mentions that important each cooperative relations between the governments require integrated management controlled together in the face of complexity that occurs in intergovernmental cooperation is built.

A good policy should be accompanied by good planning. Where in good planning will always load level indicators. In the context of this policy of free education, by the local government perceived level of indicators of implementation success yet so it is difficult to measure the extent of this program is deemed successful or less successful. The absence of indicators created by default by the provincial government in the evaluation program causing trouble. It was confirmed by the Secretary Pare-Pare that:

".... Just be sure we have no indicators, from the province's look at the how to improve the quality of education. Not only the graduation rate, but should see his teacher, growing or not. And we kombine with certification ... "(AMM, 2015)

A similar statement was also delivered by the Head of Primary Education at the Department of Education Parepare that: 
".... I think this is a weakness of the program performance indicators are not there, I challenge the province to showcase it. For example today, the funds in the scroll 9 billion for free education to Parepare, 3 billion more than the Provincial 5 billion more of us. Then we ask what means of measurement Capain use of the funds? So yesterday I said to the provinces that the challenge area for his SPM (Minimum Service Standards) of free education. For example, the number of dropouts in SPM minimum of below 1\% and now if there is a free education area nda bold guarantee that once there is a free education will reach a percentage to meet those standards? If it does not directly 1\%, could have for example the first year and 1.2\% next year down another $1.01 \%$ and has always declined. Then what about the quality of student test scores, is there any movement up or even down. Now that the province admitted to this result, the question is then where the standard of judgment? That which does not exist ..." $(A I, 2015)$.

Other problems found in the field in addition to the disbursement of funds is often too late also were often arbitrary regulation of the Governor. This is confirmed by the Head of Primary Education at the Department of Education Pare-Pare stating that:

"... The obstacles faced is not permanent regulation of the province. Every year there are regulations governor changed. And also late in the disbursement of free education, even now too late. It should be that if a new regulation is made, six months before it takes effect should have been up to the user or the target. And we're budgeting system no such thing as DPA (document platforms budget). in situ has to be stated in detail, if the DPA that we already explained and have been set in the budget and then there are different guidelines then we had to wait for a change again. Only obstacles that we face now, there needs to be labor-related regulations. Many of the children we get, let us be willing to give money, give money transport, give the book money, give clothes and they do not want. Since they became the backbone of his family to earn a living, such as parking attendants children, child laborers. This needs no regulation governing regulations governor who later followed up the area of labor-related ban on using children .... "(AI, 2015).

Related to the disbursement mechanism as afore disturbing for the government in the area. Moreover, when the provincial government would not meet the $40 \%$ quota share of the funds that have been agreed. This occurs when the district / city government can not meet the quota was agreed that $60 \%$. It was submitted by one of the key informants sexy field staff evaluation and curriculum development in Luwu Utara District education office which states that:

"... The funds that we would not thawed enough. So that liquid, junior high and elementary Only 10 months it 9 months due to a limited budget. So any help from the province we do not melt as well as when we dilute the division 40: 60 is not balanced anymore. Then it would violate the MOU ... "IIM, 2015).

Examples of how to distribute the funds between the provincial and district / city stated Head of Basic Education In Pare-Pare City Department of Education:

"... The area is proposed based on existing data such as the number of students, study rooms, teachers and others, we tell from where they made the details. When, for example Pare-Pare took 1 billion it provided the provinces and 600jt 400jt reserved area, the simple concept ... "(AI, 2015)

One very important aspect related to the effectiveness of the organizational structure that is the functioning of a coordination mechanism among all the existing structures within the intergovernmental cooperation. According to the Regional Secretary of Pare-Pare there are mistakes made by the province 
in the process of cooperation relations between this region namely the exclusion of agency cooperation in this cooperation process. Whereas the free education policy is a form of cooperation between levels of government. The results of interviews with him stating that:

".... You see, there was a mistake made diprovinsi cooperation between regions is not true, because it was not the way the cooperation bureau. Directly from the education department to the education department. It's an actual error. Should the agency that facilitates cooperation between regions. This mistake by the province. It formed cooperative relationships between the regions, the umbrella that we are in cooperation with the provincial bureau of cooperation. Because of all that work is an area of 24 districts / cities ... "(AMM, 2015)

Listening to the various issues that are relevant to aspects of the structure and management of the program has been analyzed before it can be concluded that the cause of the implementation of the free education program experienced many constraints in terms of technical and operational disbursement of funds, lack of petujuk technically capable memahmi conditions of actual on the ground, an indicator of the achievements that have not been structured either making it difficult evaluation, organizational structure has not involving the structure that should exist in every cooperation between levels of government, so also have an impact on the coordination mechanism.

\section{BIBLIOGRAPHY}

Agranoff, Robert. 1986. Intergovernmental Management: Human Service Problem-Solving in Six Metropolitan Areas. Albany, N.Y : State University of New York Press.

Akramov, Kamiljon T and Felix Asante. 2008. Decentralization and Local Public Services in Ghana: Do Geography and Ethnic Diversity Matter.

Anderson JE. 2003. Public Finance: Principles and Policy. Houghton Mifflin: Boston.

Cohen, J.M \& Peterson, S.B. 1999. Administrative Decentralization: Strategies for Developing Countries.

Connecticut: Kumahan Press.

Conlan, Timothy J. \& Paul L. Posner (ed.). 2008. Intergovernmental Management for the Twenty-First Century. Brookings Institution Press. Washington D.C.

Dauda, Carol L. 2004. The Importance of De Facto Decentralization in Primary Education in SubSaharan Africa PTAs and Local Accountability in Uganda. Journal of Planning Education and Research $200424: 28$.

Diskusi Publik, yang diselenggarakan oleh KOPEL, Yayasan Tifa pada tanggal 29 Februari 2012 di Makassar.

Denzin, Norman K \& Yvonna, S. Lincoln (eds). 1994. Handbook of Qualitative Research. Sage Publications. International Educational and Proffesional Publisher. Thousand Oaks. London New Delhi.

Domai, Tjahjunalin. 2009. Implementasi Kebijakan Kerjasama Antar Daerah Dalam Pemanfaatan Sumberdaya Daerah (Studi Kerjasama Antar Daerah dalam Perspektif Sound Governance). Disertasi. FIA-Universitas Brawajiya. Malang. 
Edner, Sheldon. 1976. Intergovernmental Policy Development. The Importance of Problem Definition. In Public Policy Making in a Federal System, ed. Charles O. Jones and Robert D. Thomas. Beverly Hilss, Cal. Sage.

Edoardo, Ongaro. Et.all. 2010. Governance and Intergovernmental Relation in The European Union and The United States (Theoritical Perspectives). Edward Elgar Publishing Limited. UK.

Gilsing, Rob. 2007. Intergovernmental Relations And The Effectiveness of Local Governance: The Case of Dutch Youth Policy. International Review of Administrative Sciences 2007 73:45. IIAS. Sage Publications (Los Angeles, London, New Delhi and Singapore). Vol 73(1):45-64 http://ras.sagepub.com/content/73/1/45.

Goldsmith, M. 2005. A New Intergovernmentalism? In B.B. Denters and L. Rose (eds). Comparing Local Governance. Trends and Developments. Pp 228-245. Pagrave: Basingstoke.

Henry, Nicholas. 2004. Public Administration and Public Affairs. Ninth Edition. Prentice Hall. New Jersey.

Irawan, Drajat. 2010. Model Kerjasaman Antar Daerah Dalam Urusan Pemerintahan (Studi Tentang Kerjasama Pemerintah Kabupaten Gresik dan Pemerintah Kabupaten Sidoarjo Dalam Pengelolaan Sampah Secara Terpadu di Bawah Koordinasi Pemerintah Provinsi Jawa Timur. Disertasi. FIA-UB. Malang.

Keban, Yeremias, T. 2007. Membangun Kerjasama Antar Pemerintah Daerah Dalam Era Otonomi. Jurnal llmu Pemerintahan Indonesia. Jakarta.

Keith, Green. 2005. Decentralization and Good Governance: The case of Indonesia. MPRA Paper No. 18097.

Lafflin, Martin. 2007. Comparative British Central-Local Relations : Regional Centralism, Governance and Intergovernmental Relations. Public Policy and Administration. SAGE Publications Ltd London. Thousand Oaks. CA and New Delhi.

Lincoln, Yvonna S. \& Egon, G. Guba. 1985. Naturalistic Inqury. Sage Publications, Beverly Hils, New Delhi, London.

Miller, William L. Et, all. 2000. Models of Local Governance: Public Opinion and Political Theory in Britain. Palgrave. Macmilan.

\section{Dokumen-Dokumen}

Peraturan Daerah Nomor 4 Tahun 2009 Tentang Penyelenggaraan Pendidikan Gratis di Provinsi Sulawesi Selatan

Undang-Undang Nomor 32 tahun 2004 Tentang Pemerintahan Daerah 